\title{
The new politics of pastoralism: identity, justice and global activism
}

Caroline Upton, University of Leicester, UK

cu5@le.ac.uk

\section{Introduction}

Renewed emphasis on struggles over the nature, manifestations and enactment of environmental justice is apparent not only in academic debates (Holifield et al., 2009; Walker, 2009a), but in new spaces and amongst new communities of interest. Previous analyses have extended the original spatial (US) and issue (race) focus of environmental justice scholarship, through attention to the "place-specific articulations of diverse environmental injustices" (Holifield et al., 2009, p. 597). However, the multiple interlinked spatialities and accountabilities contingent on the creation of new global spaces, wherein environmental justice claims may be articulated and contested, have to date received less attention. Furthermore, work on justice claimants, in the form of the transnational social and environmental movements whose representatives increasingly occupy such spaces, has frequently focused attention on "only the most visible and 'noisy' global movements...", thus neglecting emergent, less conspicuous mobilisations (Borras et al., 2008, p.173). In this paper I deploy an environmental justice framing, with particular attention to diverse dimensions and articulations of justice, to examine novel manifestations of transnational activism and the scalar dimensions of identity politics therein.

Contemporary environmental justice claims are rarely confined only to issues of resource distribution and/ or exposure to pollution (Sikor et al, this volume). Rather, demands for recognition and procedural justice have become integral to broader, trivalent conceptualizations of environmental justice (Schlosberg, 2004). ${ }^{1}$ Realisation of these multiple dimensions of justice may raise particular challenges in new global spaces, given culturally diverse understandings of environment and nature and varying emphasis on individual vs. collective rights (Sikor et al, this volume). These issues are well illustrated in the case of the global indigenous

${ }^{1}$ Following Schlosberg (2004), 'distributive justice' denotes the fair distribution of environmental goods and ills; 'procedural justice' denotes participation in decision-making and environmental policy processes by affected parties. Recognition, for example of diverse experiences, cultural identities, peoples and their right to a voice, is thus closely linked to procedural justice. 
peoples' movement. Recently recognized through the establishment of the UN Permanent Forum on Indigenous Issues (UNPFII) and in the 2007 UN Declaration on Rights of Indigenous Peoples, this identity-based mobilisation demands distributive environmental justice in the context of collective resource (especially land) rights, but explicitly grounded in notions of cognitive justice and recognition of diverse (environmental) knowledges, values and practices (UN, 2008). ${ }^{2}$ Strategic framings thus at once position indigenous activism within the remit of environmental justice concerns, highlight its socio-environmental dimensions, often through the deployment of rights-based discourses, and conflate indigenous identity with legitimacy in respect of resource access and conservation. To date, the indigenous peoples' movement remains one of the best known examples of global, identity-based struggles and activism, albeit rarely analysed specifically through an environmental justice framing (Pieck, 2006).

A comparable, partially overlapping, but distinctly less visible or 'noisy' mobilisation, namely the emergent global pastoralists' movement, has to date largely eluded sustained, critical attention. While existing work, notably by Hodgson (2011, 2002; see also Igoe, 2006), examines the strategic, global articulation of indigenous identities by East African pastoralist groups, there is little attention to i) deployment of distinctly pastoralist identities in new global spaces; ii) the construction and deployment of mobile indigenous identities, nor iii) slippages between concurrent indigenous/mobile/ and pastoralist framings within and across scales. These issues form the main focus for this paper. ${ }^{3}$ To set the scene; in the early years of the $21^{\text {st }}$ century mobile pastoralists have assumed increasing prominence in global meetings and justice claims, for example through Global Pastoralist Gatherings (e.g. Turmi, Ethiopia: 2005; Segovia, Spain: 2007), the Dana Declaration on Mobile Indigenous Peoples (2002) and the World Alliance of Mobile Indigenous Peoples (WAMIP). Through these spaces pastoralists have begun to forge an identity at once closely

\footnotetext{
2 'Cognitive justice', following Visvanathan (1998), requires explicit recognition of the existence and validity of different forms of knowledge, beyond mainstream western science.

${ }^{3}$ As Hodgson (2011) records, the idea of alternative global identity framings, for example as 'mobile peoples', was widely dismissed by her East African informants in 2005-6. In 2013, the situation has evolved significantly and merits further examination. Furthermore, while Hodgson records local reversion to pastoralist identities over time, this is analysed as a move away from indigenous framings, rather than the concurrent deployment and negotiation of multiple identities within and across scales.
} 
allied to, but also arguably distinct from, or at least a distinct strand within, global indigenism. Through the deployment of strategic framings and identity politics they have sought to articulate and realise particular visions of environmental justice across scales, through resistance to dominant discourses and injustices, and with reference to their own local constituents amongst grassroots communities. The forthcoming Global Gathering of Pastoralists in Kenya in December 2013 looks set to continue this identity-based struggle for justice (WISP, 2013).

Evidence for experiences of injustice amongst pastoral communities is widespread. Mobile or nomadic pastoralists have been particularly prone to loss of land through conservation-induced exclusion from Protected Areas; practices facilitated by their widespread representation as proponents of irrational, environmentally destructive practices (Chatty, 2003; Chatty and Colchester, 2002). Such discursive constructions or 'discursive insults' (Marino and Ribot, 2012, p. 323), wherein pastoralists appear only as people lacking the ability or knowledge to control their lifestyle, have scarcely constituted good grounds for distributive, much less procedural or cognitive justice or recognition. Recent opportunities for pastoralists to resist dominant discursive framings and to articulate justice claims arise in part from prevailing policy fashions, particularly for devolution in resource management. They also reflect aspects of international policy architecture, for example the Millennium Development Goals (MDGs), wherein donors have begun to recognise pastoral contributions to sustainable livelihoods and environments. ${ }^{4}$ Furthermore, in conservation politics pastoralists have begun to claim their own discursive ground, for example as 'custodians of the commons' and beyond concerns solely with distributive justice. Land tenure debates have also begun to recognise the efficacy of communal, customary tenure and thus question the assumed primary of individual over collective rights, with significant implications for pastoralists' legitimacy vis a vis justice claims (Sikor and Muller, 2009). Pastoralist groups have thus begun to exploit this political "landscape of opportunities..." for the reinvention of 'nomadism', and in the context of the recent successes of the indigenous peoples' movement (Pieck, 2006, p. 311).

\footnotetext{
${ }^{4}$ WISP publicity material suggests that the post-MDG Sustainable Development Goals, currently under discussion, will also be targeted by pastoralist activists as policy areas wherein pastoralist livelihoods must be considered in order for goals to be realised (WISP, 2013).
} 
This paper thus contributes to current debates over i) the global manifestations of environmental justice struggles and the links/trade-offs between different dimensions of environmental justice therein (Sikor, this volume) and ii) scalar dimensions of representation and identity in transnational activism, with particular reference to the emergent global pastoralists' movement and to dynamic framings and negotiations of identity (e.g. pastoralist, indigenous) across scales.

The material presented herein draws on empirical research at locations in Mongolia, Kenya and Spain (2009 -2010), and additional interviews with academics and activists over the same period. The research design reflected the author's concern to examine the forging of common ground and identities across axes of the greatest geographical, socio-economic and political diversity (e.g. satellite of former Soviet Union, East Africa and Europe); power differentials (e.g. established profile of Maasai in indigenous politics; relative obscurity of Mongolian pastoralists) and recent presence and activism of delegates in global spaces. In both Kenya and Mongolia semi-structured interviews were conducted with pastoralists who had attended key global meetings, and their local constituents (90 interviews). ${ }^{5}$ These participants were identified through lists provided by organisers of the global events, and/or through snowballing. ${ }^{6}$ Further interviews were conducted with NGOs who had selected and/or sponsored herders' attendance, WAMIP representatives and local administration personnel (10 interviews). In Spain interviews and discussions with key informants focused on the Segovia meeting, which the author attended. The analysis presented herein also included published and unpublished reports and online sources such as WAMIP websites.

The remainder of the paper is divided into five sections, followed by a brief conclusion. The first section addresses theoretical contexts, with specific reference to (global) environmental justice and to questions of identity and accountability in transnational activism. Subsequent empirical sections examine the nature and

\footnotetext{
${ }^{5}$ For Kenya, these included Maasai, Gabbra, II Chamus, Borana, Rendille and Endorois pastoralists, based on interviewees' self-identification, debates over the distinct status and shifting livelihood basis of some groups notwithstanding (e.g. see Anderson, 2002). For Mongolia, pastoralists constitute a much more homogenous constituency, all interviewees belonging to the Khalkh Mongol ethnic group, in common with some $80 \%$ of the total population. Mongolian interviewees did not self-identify as belonging to any subsidiary pastoralist groups.

${ }^{6}$ Snowballing describes the process by which one key informant recommends other potential interviewees, on the basis of their fulfilling particular criteria, in this case attendance at global events as a pastoralist representative.
} 
evolution of global pastoral activism; the framings of identity and dimensions of (in) justice therein; and issues of accountability and representation.

\section{Environmental justice, identity and legitimacy}

Identity politics are emerging as integral to realisation of trivalent dimensions of (global) environmental justice. Sikor (this volume) asks whether maldistributions and misrecognitions exist independently of one another, or whether (mis)recognition constitutes an overarching dimension of environmental (in)justice. ${ }^{7}$ Walker's (2009a, p. 626) contention that "misrecognition of people can be entwined with and realised through the misrecognition of places..." supports the latter position. ${ }^{8}$ I further argue that 'misrecognition' of places must encompass not only their material environmental degradation, but also diverse and contested understandings of environment and place. Through entrenched power structures, mainstream narratives of environmental degradation and conservation may effectively 'misrecognise' places from the perspectives of their inhabitants. Recognition of diverse peoples and their right to speak in global spaces enables their contestation of these views and values and hence provides spaces wherein they may challenge not only social, but also environmental misrecognition. Furthermore, recognition both enables and legitimises participation with, theoretically at least, implications for distribution, thus suggesting the mutually constitutive nature of the dimensions of environmental justice and the centrality of 'misrecognition' therein.

Identity and legitimacy in respect of justice claims may also be understood through Fraser's (2009) notion of 'misframing', wherein Westphalian, state-based framings of legitimate recipients of environmental justice are challenged and superseded in global/transnational spaces. ${ }^{9}$ Thus Chambers' (1997) old question: 'whose knowledge and whose reality counts?' is transferred upwards across scales in new vertical extensions of justice struggles, or through the process of "globalising

\footnotetext{
7 'Misrecognition', by which people and cultures are not valued, but rather subject to denigration and disrespect, is essentially the opposite of 'recognition' in environmental justice terms (Walker, 2009a, p. 626).

${ }^{8}$ By the 'misrecognition of places', Walker refers specifically to ways in which particular places may become stigmatised or devalued, for example through the siting of polluting facilities, which may then legitimise further pollution of these places.

9 'Misframing' refers to the question of who counts as a subject of justice; in particular how boundaries may be drawn around particular political or territorial spaces (Fraser, 2009).
} 
vertically" (Walker, 2009b, p. 370). In these spaces legitimacy, as the right to a voice, is often bounded through contested (and constructed) notions of identity, rather than shared membership of a polity. The example of the indigenous peoples' movement exemplifies such framings and provides critical insights into the process of collective identity formation, "criteria of belonging" (Andolina et al., 2005, p. 680) and the significance of global/transnational networks therein. Such identities may, of course, reflect the strategic appropriation of externally-generated representations (Morin and d'Anglure, 1997; Niezen, 2005). Normative visions of relations with the natural world and biodiversity conservation have historically proved especially powerful in this respect (Dove, 2006). Identity-based claims to recognition, cognitive and ultimately distributive justice frequently transcend a purely anthropocentric agenda, but link legitimacy with the capacity to deliver environmental conservation and ecological justice, questions of what "justice with and to the environment might mean" notwithstanding (Williams and Mawdsley, 2006, p. 661). As Pieck (2006, p. 322) notes, such "eco-political capital" is a somewhat unstable commodity, thus sounding a potential warning note where this is constructed as an important element of legitimacy and identity (ibid, p. 322). The varying resonance of eco-political capital across scales and its efficacy in emergent pastoralist activism is examined in Sections 3-6 below.

Finally, issues of representation and accountability merit further consideration, given that these underpin/potentially undermine prospects for environmental justice. A pervasive critique suggests that (NGO) advocates, as distinct from directly affected stakeholders, have to date predominated in global spaces of justice (Batliwala, 2002). Closer analysis of the politics and practices of representation suggest that dissenting voices are readily subsumed by 'leaders' or 'spokespersons' homogenising discourses in global spaces (Borras et al., 2008). However, Mato (2000) points out that conceptualizations of 'local' as opposed to 'global' agents in indigenous/ transnational politics tend to posit these as distinct categories. Less common is explicit recognition of the often multiple positioning of key actors, both as members of local communities, and as 'global agents' and the issues of representation and accountability which follow. 
Thus, dual questions of who occupies the 'spaces of representation', including critical questions of legitimacy and accountability, and how they do so, including shifting identity politics (for example between pastoralist, mobile peoples and indigenous identities), become critical in shaping prospects for environmental justice. The evolution of these new spaces is explored further below as a precursor to exploration of identity (politics) and accountability in the fledgling global pastoralists' movement and their deployment in pursuit of environmental justice.

\section{From grassroots to global encounters: the evolution of new spaces of justice}

Five particular manifestations of emergent global pastoral activism are explored herein: the Global Pastoralists' Gatherings at Turmi Ethiopia, 2005 and Segovia, Spain, 2007; the 2002 Dana Declaration and associated activities; WAMIP and the World Initiative for Sustainable Pastoralism (WISP).

The 2005 Turmi gathering, attended by 120 pastoralist leaders/ representatives from more than 20 countries across the Global north and south, was one of the earliest manifestations of such global activism. A donor-initiated meeting, it nonetheless opened up new spaces for cognitive, procedural and distributive justice claims and claims for recognition on the part of pastoralists themselves. ${ }^{10}$ According to its organizers, the Gathering was innovative in that "almost for the first time...[it]...put pastoral voices ahead of others in the debate about pastoral futures" (Scott-Villiers, 2005). In addition to facilitating exchanges of information, this meeting articulated a more ambitious agenda, namely to "provide a new perspective to government, NGOs and international agencies, offering understanding of the value of pastoralism, and new approaches to securing and enhancing pastoralist contributions to society, economy and the environment" (emphasis added; Turmi Global Pastoralist Gathering, 2005). In this case, the fast approaching 2015 deadline for the MDGs provided a political space of opportunity wherein pastoralist NGOs and leaders sought to advance their justice claims through reminding governments that; "in pastoralist areas of the world, these goals [MDGs] will not be met, unless new attitudes are adopted and substantial new investments are made...(and)...unless a

\footnotetext{
${ }^{10}$ The Turmi meeting was organised by the UK Department for International Development (DFID) and United Nations Office for the Coordination of Humanitarian Affairs (UNOCHA).
} 
new emphasis is placed on providing the services, markets, mobility and representation that people need" (ibid). Contrary to previous government tendencies to claim sedentarisation as a necessary precursor to service delivery (Markakis, 2004), pastoralist groups thus began to claim rights to 'development' on their own terms, but with strategic reference to international policy and development architectures. The organisers' claims regarding the novelty of the meeting are thus supported in some respects: it focused on distinctly pastoralist identities and drew together pastoralist delegates to debate directly with donors and government officials in an attempt to forge new directions in policy-making, promote recognition and wider justice claims and consolidate the key dimensions of pastoralist identity(ies). However, for all cases considered here, and as recognised elsewhere in the case of the indigenous peoples' movement, these spaces and the identities produced therein are inevitably shaped by donor/ external agendas. Global biodiversity governance regimes are a case in point here, with emergent pastoral activism attempting to speak directly to established, externally conceived agendas, even as its proponents push for justice-as-recognition in relation to other ways of knowing and encountering nature (Martin et al., 2013) .

Similarly to Turmi, the 2007 Segovia Global Pastoralists' Gathering, sponsored by WISP amongst others, brought together pastoralist representatives from over 100 countries to exchange ideas, develop common future visions and articulate their own justice claims. Publicity material for the Gathering highlights its multi-scalar and justice-oriented ambitions, through its "intention to create a space for political reflection and construction directed towards action, the support of pastoralist movements and networks on a national, regional and international level, selforganisation and greater efficiency in terms of securing beneficial policies..." (REDPASTOR, undated).

These specific events were framed within a developing institutional architecture centred around WISP, WAMIP and the 2002 Dana Declaration on Mobile Peoples and Conservation. The latter focused on conflicts, tensions and possible synergies between mainstream conservation practice and 'mobile peoples' (Chatty, 2003). It was premised on the understanding that such peoples were especially 
prone to conservation-related environmental injustices in terms of constraints on resource access, and were as yet lacking a voice in global arenas (ibid). ${ }^{11}$ The declaration was subsequently noted at the IUCN World Parks Congress (WPC) in Durban 2003, important outcomes of which were the adoption of Recommendation 5.27, 'Mobile Indigenous Peoples and Conservation', and the formation of WAMIP. ${ }^{12}$ A resolution on 'Mobile Peoples and Conservation' was subsequently formally ratified at the World Conservation Congress (WCC) in 2004. In all instances, the previous 'invisibility' of mobile peoples in debates over conservation policy and practices at extra-local scales, their frequent status as recipients of injustice and links between cultural identity, mobility and realization of conservation goals were highlighted.

WAMIP constitutes an alliance formed by mobile peoples and their representatives, with its stated mission to "assist and empower mobile indigenous peoples throughout the world to maintain their mobile lifestyles in pursuit of livelihoods and cultural identity, to sustainably manage their common property resources and to obtain the full respect of their rights" (WAMIP, 2004a, p. 3). In many ways reflecting issues highlighted by the Dana Committee, it also provides a further critical link to evolving concerns of 'mainstream' global conservation governance (as epitomized by the WPC and WCC). Despite WAMIPs' focus on mobile indigenous peoples, of whom pastoralists are only a sub group, it formed part of the organising committee for the Segovia Gathering, at which existing members were widely represented and new members recruited. The $1^{\text {st }}$ WAMIP Congress took place in Spain immediately following the Gathering. WAMIP, together with WISP and Dana Declaration representatives, are also on the Segovia Declaration Committee, formed in the aftermath of the Barcelona WPC (2008) to promote the latter Declaration and its goals. In conjunction with the Standing Committee for the Dana Declaration, WAMIP also sponsored the participation of pastoralists at the UNPFII $(2006,2008)$, including through side events exclusively for mobile indigenous peoples. The recent Dana +10 event in 2012 reaffirmed a commitment to working for environmental

\footnotetext{
11 'Mobile peoples' are therein defined as '"a subset of indigenous and traditional peoples whose livelihoods depend on extensive common property use of natural resources over an area, who use mobility as a management strategy...and who possess a distinctive cultural identity and natural resource management system" (Dana Declaration, 2002).

${ }^{12}$ The Dana Declaration was finally formally endorsed at the Barcelona WPC in 2008, with the Segovia Declaration noted in the preamble to the endorsement.
} 
justice and human rights of mobile indigenous peoples, particularly in response to conservation-related displacements and land grabbing (Chatty, 2012). It thus highlighted distributive (in)justice, but linked to recognition and underpinned by the need for procedural justice through participation in decision-making. These concerns formed the core of a statement prepared for the Rio + 20 Earth Summit (ibid, 2012).

WISP constitutes the final major initiative considered herein. As a GEFfunded, IUCN based capacity-building and advocacy initiative its stated central goal is "to achieve sustainable rangeland management through empowerment... of pastoralist communities" (WISP, undated). Amongst its commitments, it works to facilitate pastoralists to 'influence policies that impinge on their livelihoods' by amongst other goals, overcoming 'anti-pastoral prejudice", and through this to realise livelihood and conservation goals (ibid). With its origins in the $5^{\text {th }}$ COP of the United Nations Convention to Combat Desertification (UNCCD) in 2003, it is clearly located within an evolving environmental governance architecture, wherein pastoral livelihoods and justice claims may be seen as tools to facilitate achievement of externally-formulated goals.

Thus, since 2000 a range of distinct yet interconnected initiatives have opened up spaces for pastoralists to engage in global scale struggles over the nature of and access to environmental justice. This carving out of new spaces has not come without tensions between different initiatives in their pursuit of broadly shared goals. To varying degrees all engage with and/or have been shaped by existing global policy architecture and governance, for example in the form of the MDGs, UNCCD, and $\mathrm{CBD}$, wherein concerns to meet developmental and /or conservation commitments have created spaces for the strategic construction and deployment of pastoralists' justice claims, facilitated most notably through IUCN commissions and initiatives, and with challenges to previous misrecognition of pastoralists at their core.

The issue of how pastoralist identities are constructed and deployed, and strategic slippages between pastoralist, indigenous and 'mobile peoples' identities are explored in the following sections, with reference to issues of (mis) recognition and the wider environmental justice framing. First it is important to map pertinent dimensions of injustice for pastoralists and 'mobile indigenous peoples'. 


\section{Dimensions of (in)justice}

Articulations of injustice within these new global arenas draw on shared historical experiences, contingent on shared modes of production or, in the case of WAMIP at least, upon common practices of mobility. Common ground is thus sought not only in aspects of livelihoods but in these very experiences of injustice and forged through a series of strategic simplifications ( $\mathrm{Li}, 2002)$. For example, according to one key WAMIP informant, "the commonality lies in the fact that all these groups [mobile indigenous peoples] are marginalised...marginalisation would perhaps be the broader term which will make these people rally together and have a common purpose [through asking]...how do we get out of this marginalisation, how do we get access to and control of our resources?" (interviews, 2009). The purportedly common experience of marginalisation thus facilitates mutual recognition (Igoe, 2006), albeit being better served by varying emphasis on pastoralist/ mobile indigenous/ indigenous identities in particular spaces and across scales (Section 5).

Dimensions of injustice, as claimed in official pronouncements and by global pastoralist delegates in interviews, encompass the three elements of distribution, participation and recognition. Claims to distributive injustice centre on loss of resources, especially land access, primarily through protected areas, mining and sedentary agriculture. For example, pastoralists' disenfranchisement and loss of grazing land to mining is a central issue in Mongolia. At the time of writing a number of cases brought by a local human rights NGO on behalf of displaced herders remained unresolved. As Mongolian delegates to the UNPFII complained, "herders are the people most (adversely) affected ...", whilst having few rights of redress (pastoralist interviews, Mongolia, 2009). ${ }^{13}$ In Kenya, loss of pastoral lands to biodiversity conservation, and alternative land uses through privatisation of rangelands were the most commonly reported manifestations of land grabbing (pastoralist interviews, Kenya; Galaty, 2013). According to the Segovia Declaration, "in many societies, governments have 'nationalised' and confiscated rangelands, forests and other natural resources on which pastoralists depend... alienating

13 Interviewees are not identified further at their own request in order to ensure confidentiality and anonymity. 
nomadic pastoralists from their natural rights" (Segovia Declaration, 2007). Rightsbased discourses around land are also evident in material from WAMIP, WISP and the Dana Declaration. Distributive injustice is also invoked in reference to pastoralists' often limited access to education and healthcare (Segovia Declaration, 2007; interviews 2009).

These distributive justice claims are framed within struggles for procedural justice and overarching claims for recognition. Dana and Segovia Declarations and the WISP agenda all require mobile peoples/ pastoralists "full participation in decision-making and relevant negotiation processes at different levels" (Dana Declaration, 2002). In particular, claims for diverse aspects of recognition are central to pastoralist/ mobile indigenous peoples' agendas. Misrecognition of pastoralists continues to be evident; according to WISP (undated) "mobile pastoralists... are subject to an astonishing number of myths and misconceptions [which] have led to inadequate, often hostile development policies and interventions... In order to achieve the twin goals of dryland environmental sustainability and pastoral poverty reduction it is necessary to overcome anti-pastoral prejudice...". Thus here, and as previously suggested, environmental and social misrecognition are closely intertwined, with in this instance eco-political capital affording pastoralists a useful tool through which to contest aspects of misrecognition, albeit not being without its own inherent dangers (Pieck, 2006).

It is nonetheless fortuitous for emergent global pastoral activism that institutions and mechanisms of global governance have to some extent facilitated challenges to long-established dimensions of misrecognition. These challenges are in part framed within a human rights agenda, and in this respect at least closely mirror established indigenous peoples' framings. However, much of this reinvention relies on challenges to entrenched discourses concerning pastoral livelihoods and the environment, facilitated by strategic links to instruments such as the UNCCD and conservation accords grounded in the CBD. While discursive constructions of pastoralists as irrational and environmentally destructive have historically facilitated their exclusion from distributive and procedural justice, aspects of contemporary global environmental governance are implicated in the incipient "reinvention of 
pastoralism" (Markakis, 2004). Recent WISP reports present "pastoralism as conservation in the drylands" (WISP, 2008). As an organization arising directly from the UNCCD $6^{\text {th }}$ COP, this positioning of pastoralism is integral to the WISP agenda and has also been adopted by WAMIP and Segovia attendees, with presentation of the Segovia Declaration to the UNCCD $8^{\text {th }}$ COP in Madrid, 2007. The Dana Declaration, endorsed in mainstream conservation fora such as the WPC, is specifically positioned as "an attempt to forge a new partnership between conservationists and mobile peoples", premised not only on a rights-based agenda, but on the conservation benefits of mobility (Refugee Studies Centre, undated). ${ }^{14}$ However, while pastoral delegates from Kenya and Mongolia were complicit with this 'conservation framing' and deployment of eco-political capital at the global scale, it was less commonly highlighted in local and regional struggles, wherein demands for justice were typically framed in terms of customary land rights/usage and associated cultural rights. Strategic inconsistencies or slippages in framings, identities and justice claims across scales are illustrated for Mongolia and Kenya below, following exploration of the construction of pastoralist and 'mobile indigenous peoples' identities.

\section{Claiming justice: recognition and identity}

Hodgson (2002, p.1090) reports a meeting of indigenous NGOs in Tanzania, wherein the question of whether 'common interests' or 'shared identity' should be the primary markers of belonging arose as a focus for critical debate. At the core lay questions of 'who is a pastoralist?' and 'what does it mean to organize around a shared identity as pastoralists?' especially given the contested, dynamic and fragmented nature of such identities. Recent environmental justice scholarship highlights the 'politics of recognition' as integral to realization of justice claims (Williams and Mawdsley, 2006; Tschakert, 2009). In the case of emergent global pastoral activism, identity and its recognition/ misrecognition emerge as essential pre-requisites in articulating and realizing claims for (procedural and distributive)

\footnotetext{
${ }^{14}$ Of course contemporary re-presentations and reworkings of pastoralism/ conservation relationships cannot be ascribed solely to environmental justice concerns, but may reflect a range of motives amongst key actors. Thanks to an anonymous reviewer for this important point.
} 
justice. But how are identity-based demands for recognition framed in this instance, especially given the diversity not only of inter but also intra-national pastoralist groups? Changes in pastoral livelihoods to encompass partial dependence on agriculture suggests that contemporary "pastoralism [should be understood as]... a mode of perception as well as a mode of production" (Markakis, 2004, p.14), "pure pastoralism' or the 'pastoral ideal' (Igoe, 2006, p. 408) being increasingly under threat. This is reflected amongst interviewees, especially in Kenya and across the diverse Kenyan pastoralist groups interviewed. According to one informant, "yes, certain pastoralists adopt crop farming...but [I have] found that they adopt that particular lifestyle just because they have lost their animals... as soon as they have rebuilt their critical numbers...they will always abandon whatever they are doing and return to pastoralism. So ...I would regard that person as a pastoralist even if they settle down because they still have that pastoralist thinking and mentality" (pastoralist interviews, Kenya, 2009). Another provided an emotive account of pastoral identities; "pastoralism is the system that you are based in... it is you, how you love it, how you value it... so the moment you separate me from this system...you are killing me..." (pastoralist interviews, Kenya, 2009). These statements must however, be understood in a wider context of trends of livelihood diversification and decreased pastoral mobility. As Homewood et al. (2009) report, 'staying Maasai' in modern day Kenya increasingly necessitates livelihood diversification including into 'non-farm activities, as well as cultivation, with attendant impacts on mobility, even while livestock ownership remains central.

Local realities and representations notwithstanding, the framing of pastoralist identities in the new global spaces highlighted above share a number of significant commonalities. These include mobility in pursuit of livelihoods, reliance on common property, governed by customary rules and tenure, and thus collaborative rather than individualistic strategies and dependence primarily on livestock. These multiple aspects serve to represent pastoralism both as "an adaptive production strategy assuring the economic survival of hundreds of millions of people as well as a way of life contributing to the sustainable management of natural resources and the conservation of nature" (Segovia Declaration, 2007). The importance of local and 
indigenous knowledge is also emphasized, in claims to solidarity between pastoralists "regardless of distinctions of class, gender, religion, ethnicity, caste, nationality and culture" (ibid). Thus a shared mode of production, at least in the context of global pastoralists' gatherings, is constituted as having greater weight than these axes of diversity, thus enabling a highly simplified construction and representation of pastoral identity, in other words, a strategic simplification, in which deviation from the 'pastoral ideal' is elided in the construction of commonality. Elsewhere however, mobility, in itself a strategic simplification given widespread trends towards sedentarisation, is represented as a core dimension of identity, thus extending fluid and contested 'boundaries of belonging' to incorporate the newly defined category of 'mobile indigenous peoples'.

In early discussions around the formation of WAMIP, the terminology used to denote these boundaries was critical. According to unpublished WAMIP sources; "taking into account the discussion on international law and Indigenous Peoples during the World Parks Congress (WPC), it was agreed by consensus to temporarily use the term "Mobile Indigenous Peoples" (emphasis in original). This specific deployment of identity represents a contrast with the preceding Dana Declaration (2002), which purports to deal only with 'Mobile Peoples'. Nonetheless, WAMIP's definition of mobile indigenous peoples (i.e. nomadic pastoralists, shifting agriculturalists and hunter gatherers) is essentially identical to that of 'mobile peoples' in the Dana Declaration (footnote 4, WPC, 2003). Thus through WAMIP and Dana mobility became a key defining characteristic, over and above a shared mode of production and despite the predominance of pastoralists in WAMIP (interviews, 2009, 2010). As one Kenyan informant explained, "there are diverse people who depend on mobility for their livelihoods. So I think it was felt that there should be a more unifying body for all those people ... and that is how the term Mobile Indigenous People came into being... there is a lot of attention on indigenous people.. [but] the mobile ones happen to be given less attention within this... they are kind of the marginalised within the marginalised" (NGO interviews, Kenya, 2009). Reports of the creation of WAMIP at the Durban meeting concur that, despite some previous participation in the wider indigenous peoples' movement, mobile indigenous peoples' particular 
vulnerability and needs were yet to be recognised or addressed, thus necessitating the formation of a body such as WAMIP (Castelo, undated). Again the construction of this identity is, of course, a strategic simplification, with the emphasis on mobility reflecting not only actual practice but perceived rights to mobility, on the basis of historical precedents (Chatty, 2013; MARAG, 2010).

This specific articulation of 'indigeneity' in 'mobile indigenous peoples' represents a strategic link with established global recognition of indigenous rights and identities, not merely an expression of solidarity, as suggested in some WAMIP reports (WAMIP, 2004b). According to one WISP commentator, "pastoralists are benefitting from the indigenous movement... capitalizing on it... it's a shrewd move..." (interviews, 2009). This deployment of 'mobile indigenous' as opposed to solely 'pastoralist' framings has not however gone uncontested, with some Segovia attendees concerned that the former may prove too broad to secure common interests and sustain activism (pastoralist interviews, 2009, 2010). Furthermore, for pastoralists the value of indigenous identity vis a vis prospects for justice varies both with scale and geographical context. The case studies of Mongolia and Kenya shed further light on scalar contrasts in and slippages between pastoralist/ mobile indigenous/ indigenous identities and the politics of representation in pursuit of environmental justice.

In Mongolia, informants suggested that indigenous, rather than pastoralist, identities have historically enjoyed limited resonance in domestic spaces. Recent understandings of indigeneity in relation to minority rather than 'first peoples' status, remain challenging in Mongolia, given the continuing importance of (nomadic) pastoralism as a component both of Mongolian national identity and some $30 \%$ of local livelihoods. Nonetheless, as noted for East African pastoralists in the 1990s (Hodgson, 2011; Igoe, 2006), the indigenous category has become salient, primarily at the global scale, and in relation to alleged discrimination and marginalisation in the face of particular forms of 'development'. Thus, while pastoralist identity retains greater national and local resonance, Mongolian pastoralists engage with mobile indigenous identity framings at the global scale through WAMIP, for example at UNPFII meetings (pastoralist and NGO interviews, Mongolia, 2009). According to one 
Mongolian UNPFII delegate, WAMIP events have afforded them the opportunity to explore common challenges to livelihoods and ways to strengthen a mobile indigenous/ pastoralist movement (interviews, Mongolia 2009). Mobile indigenous identities, ascribed though self-identification and mutual recognition, have thus proved complementary to emphasis on pastoralist identities in spaces such as the Segovia gathering, with Mongolian delegates moving readily between these global spaces and identities (ibid, 2009). Furthermore, while eco-political capital has resonance for Mongolian pastoralists at the global scale, wherein it underpins demands for recognition as an overarching dimension of environmental justice, in domestic politics concerns were more commonly framed in terms of customary land rights/usage and land relations and with emphasis on distributive justice. The case of struggles over mining-related land alienation provides a good illustration of scalar issues. Statements in the global spaces/ events highlighted in Section 3 stress the conservation benefits of Mongolian pastoralists'/ mobile indigenous peoples' traditional land use practices and emphasise the profound distributive injustice of mining-related losses. Recent anti-mining activism further suggests the success of particular 'strategies of extraversion' (Igoe, 2006) through emphasis on the conservation and environmental benefits of traditional nomadic pastoralism contra mining. ${ }^{15}$ Struggles over justice in relation to major internationally-operated mining developments in Mongolia's Gobi region stress the indigenous rights and identities of affected pastoralists through reference to international norms and standards for free, prior and informed consent of indigenous peoples. In primarily domestic politics however, the issue of pastoralists' customary land rights, usage and alienation is at the centre of debates over development of new pasture legislation and tradeoffs between mining and herding. Pastoral group tenure arrangements, grounded to varying degrees in 'customary rights' are currently being supported by a range of initiatives and with direct appeal to ideas of distributive justice (Upton, 2012). Thus, across scales claims to environmental justice are variously linked to indigenous and/or pastoralist identities and thus to recognition, although calls for procedural

\footnotetext{
${ }^{15}$ For example the pastoralist leader of Mongolia's grassroots Onggi River Movement, was awarded the international Goldman Environmental Prize in 2007 for his work on conservation/protection of natural resources, especially water, in the face of mining impacts (Upton, 2012). However, the Movement's framings and representations in domestic spaces provide a more nuanced emphasis on customary land rights, linked to cultural and spiritual relations with land, and the livelihood impacts of mining.
} 
justice and recognition are particularly apparent at the global scale, wherein greater emphasis is placed on eco-political capital as a dimension of pastoralists' legitimacy.

In Kenya the recent Endorois land claim at Lake Bogoria provides a similar illustration of scalar contrasts and negotiations in framings of justice claims. Indigenous identity arguably only become salient for many African peoples in the 1990s, with the move away from the emphasis on First Peoples status, towards experiences of marginalisation, minority status and cultural distinctiveness (Igoe, 2006; Niezen, 2003). For many peoples, these attributes mapped neatly onto minority pastoralist or hunter-gatherer livelihoods (contra Mongolia) and thus also onto mobility. Nonetheless, and despite this apparent conflation of 'mobile indigenous' and pastoralist identities, there are scalar variations in the emphasis on these identities in pursuit of particular dimensions of environmental justice. As one informant argued, "in Kenya, the question of who is indigenous is not very clear...our government refuses to accept the UN resolution on indigenous peoples...". (pastoralist and NGO leader, interview, Kenya, 2009). A key actor in WAMIP similarly indicated a disjuncture between identity framings in purely domestic contexts, wherein the Kenyan government was more likely to respond to a 'pastoralist' framing, and indigenous framings with currency in regional and global spaces. Specifically, he argued that "there is (currently) no real structure [for global pastoral activism and justice claims]....two years ago Kenya was visited by the UN Special Rapporteur on indigenous peoples... to look at the issues of indigenous peoples - in the case of Kenya, these are pastoralists - but if we had already distinguished ourselves [from the indigenous peoples' movement] he would not have come.... (ibid, 2009). Thus, by this account the fledging global pastoralists' movement currently appears weak in contrast to the indigenous peoples' movement in terms of its prospects for delivering justice through global spaces and as part of strategies of extraversion, while domestically, pastoralist identities retain greater salience. ${ }^{16}$ The recent Endorois land claim, further underlines the strategic reasons for this indigenous framing at regional and international scales.

\footnotetext{
${ }^{16}$ This mirrors Hodgson's (2011) conclusions in relation to Tanzania, Of course the greater salience of pastoralist than indigenous identities in Kenya's domestic politics does not necessarily translate into action, although Elmi and Birch (2013) note the recent opening up of new domestic policy space for pastoralism.
} 
Through this case, the displacement of Endorois pastoralists from Kenya's Lake Bogoria National Nature Reserve in the 1970s was overturned by the African Commission on Human and Peoples' Rights, based largely on the recognition and construction of Endorois' indigenous identity (Lynch, 2011) The Judgement argued that "the [Kenyan] state ... has a duty to recognize the right to property of members of the Endorois community, within the framework of a communal property system" and duly recommended redress in accordance with the precepts of the African Convention on Human and Peoples Rights (ACHPR) (CEMIRIDE/MRGI, 2010). The Endorois judgement further argued that "the alleged violations of the African Charter are those that go to the heart of indigenous rights - the right to preserve one's identity through identification with ancestral lands" (CEMIRIDE/MRGI, 2010, para. 162). Thus communal indigenous (rather than specifically pastoral) land rights are conflated with culture and identity in this regional and international framing.

Overall therefore, tensions are apparent in framing of justice claims and grounds for legitimacy at diverse scales. In new global spaces pastoralists' prospects for delivering ecological justice, through conservation benefits of their 'traditional' livelihoods and practices, appear integral to redressing norms of misrecognition and legitimising claims for not only distributive, but also procedural and even cognitive justice. Aspects of pastoralist identities as deployed at this scale at times come close to (self)-representation as 'ecosystem people' (Williams and Mawdsley, 2006: 663). However, the potential risks implicit in such representations are obvious, as recognized in WISPs insistence on the dynamism and complexity of contemporary pastoral livelihoods (WISP, undated). Livelihoods and rights-based discourses are also obviously important, especially where strategic links are made to indigenous identities and frameworks for indigenous peoples' rights. Nonetheless, the emphasis on conservation and sustainable land use in relation to global pastoralist identities is striking. At other scales and also in relation to indigenous identities, recognition of resource rights and hence distributive justice, grounded in notions of custom and culture were more important justice concerns.

In the final empirical section of this paper, below, I examine issues of crossscalar accountability, representation and efficacy. 


\section{Accountability, representation and grassroots justice}

Reports from the 2005 Turmi Gathering claim, "our target participants were not the usual easily-identified workshop-goers. We had to bypass the ones who said they could speak for pastoralists and get the real leadership...they had to be mandated by their people to attend the gathering and report back whatever had transpired" (ScottVilliers et al., 2005). The Segovia Gathering aimed for similar attendees, with "the predominance of pastoralists...seen as integral to realisation of goals". Full involvement and participation of grassroots peoples was further highlighted as an important aspect of legitimacy, and by extension of procedural justice, by key actors in the emergence and development of the initiatives considered herein (interviews, 2009; REDPASTOR, 2007). The fledgling global pastoralists' movement is by no means the first to challenge the entrenched "politics of representation", by which advocates often predominate over grassroots stakeholders in global arenas (Batliwala, 2002). Nonetheless, the apparent commitment to representative justice in emergent pastoral activism is notable, although its enactment has proved more problematic.

For the Segovia Gathering, the official selection procedure required recommendations from in-country NGOs and donors for 'grassroots' pastoralists who would "represent the communities that actually practice mobility of people or herds... (and who were) nominated by their own communities" (interviews, 2009). Local communities were also to be fully engaged in shaping the scope and responsibilities of representation (interviews, 2009). In this respect, the process appears to offer more formalised procedures for engagement of the grassroots than, for example, the initial Dana meeting in 2002 (interviews, 2009, 2010). ${ }^{17}$ However, NGO/ donor intermediaries still played a significant role. Resultant attendees at Segovia comprised a mixture of pastoralists, including a high number of WAMIP members, and NGO leaders, with limited numbers of academics and 'experts'. Key informant interviews suggested that "at Segovia the selection process was not quite right...",

\footnotetext{
${ }^{17}$ Arising from a conference of scientists and NGOs, the meeting and subsequent Declaration involved both grassroots and nongrassroots participants, a focus of critique for some (interviews 2009, 2010). However, subsequent Dana-sponsored attendees at global meetings were typically pastoralists identified through NGO intermediaries (ibid, but see also note 18, below).
} 
with the full engagement and legitimate representation of pastoralist communities still proving elusive. For side events at the UNPFII, and the WCC (2008), criteria for attendance were less clear cut, albeit at least in the latter instance apparently focusing on more senior pastoral intermediaries. ${ }^{18}$

For Mongolian attendees at Segovia, UNPFII and other key events, development NGOs, notably the New Zealand Nature Institute (NZNI)/ GTZ, played an important role in their selection as community representatives (interviews, Mongolia, 2009, 2010). Following in-country identification by project staff of the most active pastoralists, especially amongst leaders of donor-initiated herders' community groups (nukhurlul), selections were typically confirmed in discussion amongst nukhurlul members. As one project employee stated, "yes, herders also had their voice...we would tell them "there is this meeting, who do you think should go?" ... it wasn't just our decision..." (interviews, Mongolia, 2009). Nonetheless, one global delegate stated; "It is really GTZ who choose... herders make suggestions but the main role is GTZ's ...other nukhurlul members are happy with this..." The role and mandate of representatives was also called into question: pastoralist interviewees described how a minority of local families offered informal suggestions concerning important issues to be raised at global meetings, but with no real sense of a mandate to be fulfilled (interviews, 2009).

Similarly, a Kenyan delegate to Segovia, selected by the Pastoralists Development Network of Kenya (PDNK), ${ }^{19}$ with little apparent remit from a local pastoralist constituency, highlighted weak chains of accountability and representative responsibilities, these being confined to sharing information about the forum after the event on a rather ad hoc basis. Two others, selected by a local pastoral NGO representative to attend the Turmi gathering, similarly indicated little by way of a clear mandate from other local pastoralists. Feedback was provided to local community members on their return through formal and informal meetings, facilitated in one case by the sponsoring NGO and including distribution of 'Rain Prosperity and Peace' booklets, albeit only in English (interviews, Kenya, 2009).

\footnotetext{
18 Of 8 mobile indigenous peoples' representatives sponsored by the Dana Committee and WAMIP to attend the latter event, 6 held official posts within the WAMIP hierarchy (e.g. as councillors, treasurer etc) (pers. comm, 2008).

${ }^{19}$ An advocacy NGO and network comprising diverse pastoralist organisations, individuals and support bodies across Kenya.
} 
Thus, the nature of accountability and legitimacy in terms of grassroots representatives and their local constituencies are still to be fully mapped out, with active engagement by local communities, including in shaping the scope and responsibilities of representation, somewhat limited at present.

Issues arise here with respect to links between representation, accountability and efficacy. One informant argued "there are actually two categories of people [who go to international meetings]... there are the national level people who champion issues of pastoralists and there are the grassroots...the people from the national level, they get information... but here on the ground ... we rarely get this information... also you always get the same people going to these global meetings..." (interviews, Kenya., 2009). Another stated "what I'm seeing now is this; the resolutions of global meetings are perfect, but the government comes and shelves [them], they put them aside and it's very easy....those attending these global meetings are well organized [bodies], NGOs... they have developed good support with the government, so they respect each other" (interviews, Kenya, 2009). Thus, pastoralist interviewees indicated concerns over the perceived extent of nongrassroots representation, and the lack of accountability and efficacy of such delegates. However, one senior WAMIP member argued "I think it is better to have criteria developed, so that you only send people who have a global understanding... [at least to UN meetings]... who can put their point across in a manner that others will understand... if we take someone... who is just an elder, as somebody fighting for the rights of mobile people and [we] take him to New York, he may not be very effective...". Issues of efficacy thus arise in respect of both grassroots and nongrassroots representation. As one Kenyan NGO delegate observed, "I haven't really seen any results from Segovia... the recommendations from Segovia...[which encompass all three aspects of justice]...need to be debated here to see what we can get the government to do... but there are no horizontal links, I couldn't organize anything" (interviews, Kenya, 2009), A Mongolian pastoralist representative concurred, "[two people] went to Spain [Segovia] and afterwards they did broadcasts on TV... and some interviews... but there was no clear policy behind this... the [local] administration just say OK, but they don't do anything...". The status of WAMIP, as 
one of the organizations associated with the Segovia Declaration, was also highlighted as a critical factor by some; "if I come and tell my government WAMIP declared this, they will tell you "what is WAMIP? Who is it?" (interviews, Kenya, 2009).

These issues of recognition, legitimacy and weak cross-scalar linkages, with their implications for efficacy, remained important issues of concern amongst pastoralist delegates, the scalar politics outlined in Section 5 notwithstanding. Nonetheless, despite the limitations highlighted above, it was widely acknowledged amongst interviewees that the key initiatives considered herein were an important initial step, as one Kenyan delegate argued, "Segovia was valuable as a learning process and as a way of developing a common agenda and creating a critical mass in our own country". A Mongolian delegate to a UN Indigenous Peoples' Forum meeting concurred, "today a meeting is held and tomorrow life changes"... well of course it is nothing like that, but in the long run herders will get more information...so slowly our lives improve...." (interviews, Mongolia, 2009). Overall, while prospects for full realisation of environmental justice goals remain in the future, emergent pastoral activism was widely welcomed by interviewees as part of an important if lengthy process in pursuit of justice, and one in which recognition and identity politics were central.

\section{Conclusions}

According to a Mongolian delegate at Turmi, "because of this meeting, over the next ten years pastoralists' lives will improve. The world will now hear pastoralists' voices and when they go home they will be able to affect the local government which will affect the regional government which will affect the national government which will affect international organizations..." (cited in Scott-Villiers et al., 2005). The evidence presented herein indicates that this analysis was highly over-optimistic. Nonetheless, emergent global pastoral activism merits recognition as an important aspect of contemporary global environmental justice struggles, in both theoretical and practical aspects. 
The strategic formation and deployment of identity emerges as an important element in conferring legitimacy, contesting 'misframing' and hence in shaping justice claims (Fraser, 2009). Through deployment of pastoralist, indigenous and/or 'mobile peoples' identities, pastoralists have been able to forge strategic links with the established indigenous peoples' movement, its political capital and global architecture, as exemplified in the UNPFII. Key informants cited herein have furthermore highlighted the particular resonance and efficacy of different identity framings at different scales and in different spaces. As Sikor et al. (this volume) suggest, misrecognition emerges as an overarching dimension of injustice in this case, contested at least in part through these strategic deployments of identity. However in this instance, in contrast to many documented cases of transnational activism, challenges to established norms of misrecognition, exemplified in discourses of the environmental destructive pastoralist, have not originated solely from the grassroots but rather have been strengthened by the complicity of particular aspects of global governance regimes. The incipient 'reinvention of pastoralism', especially vis a vis conservation, has been shaped by new representations, knowledges and discourses linked for example to the UNCCD and CBD, in the latter case specifically through recent WPC and WCC meetings. Pastoralists' engagement with these new representations and opportunities in global spaces is not, however, without its dangers. Legitimacy, as recipients of procedural, cognitive and distributive justice, readily becomes intertwined with and premised on their capacity to deliver ecological justice; a precarious position given the instability of eco-political capital, in itself a potential misframing (Pieck, 2006). For example, other ways of knowing and valuing nature may be subsumed to mainstream conservation discourses in attempts to construct and deploy effective eco-political capital (Martin et al., 2013). At national and sub-national scales and also in relation to indigenous identities, justice claims grounded in rights-based discourses were more prevalent for the cases considered herein, highlighting a degree of tension between ways in which legitimacy is understood and realised across scales. Rights-based claims, for example to land and cultural recognition, also fit more readily within the established indigenous frame, as exemplified by the Endorois case in Kenya. 
Issues of accountability and representation also emerge as important dimensions of justice struggles. Specifically, by local constituents' accounts, nonpastoralists may be less able to deliver justice in terms of representation and recognition to pastoralists at the grassroots and, by definition, tend to close down prospects for full realisation of procedural and even cognitive justice at global scales. However, the experiences of returning 'grassroots' pastoralist delegates in their home countries suggests that prospects for realisation of distributive justice may be enhanced by enrolment of just such representatives in order to facilitate policymakers engagement, in conjunction with better support from bodies such as WAMIP. Thus, unresolved tensions remain between representation, accountability and efficacy in emergent pastoralist activism.

Such considerations make any attempt to evaluate the success of emergent global pastoral activism in delivering environmental justice necessarily problematic. Borras et al's (2008) evaluation of the effectiveness of global campaigns through a series of stages is useful here. On a scale between 1 '(framing debates and getting issues on the agenda)' and 5 '(influencing behaviour changes in target actors)', pastoral activism is at the lower end of the scale (ibid, 269). Through meetings and declarations, pastoral justice issues have clearly emerged onto the global agenda, with gains in terms of recognition and cognitive justice. Discursive commitments have also been secured from a number of policy actors in conjunction with global governance regimes, if not from nation states, again with implications for recognition, cognitive, but also procedural justice (stage 2). Procedural changes have also been realised to some degree at the international if not the national level, for example through the presence of WAMIP at the UNPFII, again with benefits particularly in terms of procedural justice (stage 3). Clear effects on policy (stage 4) and target actors (stage 5) cannot really be claimed at this juncture, and thus gains in distributive justice have yet to be realised, given that the successful Endorois case emanated primarily from a regional, indigenous rather than global pastoralist framing. ${ }^{20}$ However, given the very recent appearance of global pastoral activism, any expectations for material changes in distributive justice seem premature.

\footnotetext{
${ }^{20}$ There are also issues and delays with the full enactment of the African Commission judgement in the Endorois case.
} 
Meeting organisers, WAMIP members and grassroots pastoralists concurred that exchanges in information between pastoralist groups, identification of core areas of commonality and forging an agenda for the future were in themselves important achievements and manifestations of 'success', at such an early stage. Although the vision of the Mongolian delegate cited above seems unrealisable by 2015, prospects for realisation of trivalent environmental justice concerns over the long term may be deemed strengthened by emergent and ongoing dimensions of pastoral activism. 


\section{References}

Anderson, D. 2002. Eroding the Commons: The Politics of Ecology in Baringo, Kenya 1890-1963. Athens: Ohio University Press.

Andolina, R., Radcliffe, S., Laurie, N. 2005. Development and culture: transnational identity making in Bolivia. Political Geography 24 (6), 678-702.

Batliwala, S. 2002. Grassroots movements as transnational actors: implications for global civil society. Voluntas 13 (4), 393-409.

Borras, S., Edelman, M., Kay, C. 2008. Transnational agrarian movements: origins and politics, campaigns and impact. Journal of Agrarian Change 8 (2 \& 3), 169-204.

Castelo, M. Undated. Mobile Indigenous Peoples Travel for First Time to a World Parks Congress. http://www.danadeclaration.org/pdf/Castelo.pdf

Centre for Minority Rights Development (Kenya) (CEMIRIDE) and Minority Rights Group International (MRG). 2010. Centre for Minority Rights Development (Kenya) and Minority Rights Group International on behalf of Endorois Welfare Council v Kenya. Communication released by African Commission on Human and Peoples Rights.

http://terra0nullius.wordpress.com/2010/02/17/the-african-commission-endoroiscase-toward-a-global-doctrine-of-customary-tenure/.

Chambers, R. 1997. Whose Reality Counts? Putting the First Last. Intermediate Technology Publications, London.

Chatty, D. 2012. Workshop report: Dana Declaration +10 . Refugee Studies Centre, Oxford Department of International Development, Oxford.

http://www.danadeclaration.org/dana10/dana-participant-statement-en.pdf.

Chatty, D. 2003. Mobile peoples and conservation: an introduction. Nomadic Peoples 7 (1), 5-16.

Chatty, D., Colchester, M. 2002. Introduction: conservation and mobile indigenous peoples. In Chatty, D., Colchester, M. (Eds.) Conservation and Mobile Indigenous Peoples, Berghahn Books, Oxford, pp. 1-20.

Dana Declaration. 2002. Dana Declaration on Mobile Peoples and Conservation. http://www.danadeclaration.org.

Dove, M. 2006. Indigenous peoples and environmental politics. Annual Review of Anthropology 35,191-208. 
Elmi, M. and Birch, I. 2013. Creating policy space for pastoralism in Kenya. Future Agricultures Working Paper 068. IDS, Sussex.

http://opendocs.ids.ac.uk/opendocs/handle/123456789/2926\#.UniqJcxFDIU

Fraser, N. 2009. Who counts? Dilemmas of justice in a postwestphalian world. Antipode 41, 281-297.

Galaty, J. Land grabbing in the Eastern African rangelands. In Catley, A., Lind, J. and Scoones, I. (Eds.) Pastoralism and Development in Africa. Routledge, London, pp. 143-153.

Hodgson, D. 2011. Being Maasai, Becoming Indigenous: Postcolonial Politics in a Neoliberal World. Indiana University Press: Bloomington.

Hodgson, D. 2002. Precarious alliances: the cultural politics and structural predicaments of the indigenous rights movement in Tanzania. American Anthropologist 104 (4),1084-1097.

Holifield, R., Porter, M., Walker, G. 2009. Introduction. Spaces of environmental justice: frameworks for critical engagement. Antipode 41 (4), 591-612.

Homewood, K., Kristjanson, P., Chenevix Trench, P. (Eds.). 2009. Staying Maasai? Livelihoods, Conservation and Development in East African Rangelands. Springer: New York.

Igoe, J. 2006. Becoming indigenous peoples: difference, inequality, and the globalization of East African identity politics. African Affairs 105 (420), 399-420.

Li, T. 2002. Engaging simplifications: community-based resource management, market processes and state agendas in upland Southeast Asia. World Development 30 (2), 265-283.

Lynch, G. 2011. Becoming indigenous in the pursuit of justice: The African Commission on Human and Peoples' Rights and the Endorois. African Affairs 111 (442), 24-45.

MARAG. 2010. Summary report and global action plan: women pastoralists. Outcomes and next steps from the global gathering of women pastoralists, Meera, India. November 21-26, 2010.

Markakis, J. 2004. Pastoralism on the margin. Minority Rights Group International. http://www.minorityrights.org/1054/reports/pastoralism-on-the-margin.html.

Marino, E. and Ribot, J. 2012. Special Issue Introduction: Adding insult to injury: Climate change and the inequities of climate intervention. Global Environmental Change 22 (2), 323-328. 
Martin, A., McGuire, S., Sullivan, S. 2013. Global environmental justice and biodiversity conservation. The Geographical Journal 197 (2): 122-131.

Mato, D. 2000. Transnational networking and the social production of representations of identities by indigenous peoples' organizations of Latin America. International Sociology 15, 343-360.

Morin, F. and d'Anglure, B. 1997. Ethnicity as a political tool for indigenous peoples. In Govers, C. and Vermeulen, H. (Eds.). The politics of ethnic consciousness. Macmillan Press, Basingstoke, pp. 157-193.

Niezen, R. 2005. Digital identity: the construction of virtual selfhood in the indigenous peoples' movement. Comparative Studies in Society and History 47, 532-551.

Niezen, R. 2003. The Origins of Indigenism: Human Rights and the Politics of Identity. University of California Press, Berkeley.

Pieck, S. 2006. Opportunities for transnational indigenous eco-politics: the changing landscape of the new millennium. Global Networks 6 (3), 309-329.

REDPASTOR. 2007. World gathering of nomadic and transhumant pastoralists: Nominee form for representatives of nomadic and transhumant pastoralists. Unpublished source.

REDPASTOR. Undated. The history of the $1^{\text {st }}$ World congress of nomadic and transhumant peoples. Unpublished source.

Refugee Studies Centre. Undated. The Dana Declaration: information booklet. Unpublished report, University of Oxford.

Segovia Declaration. 2007. Segovia Declaration of nomadic and transhumant pastoralists. La Granja, Segovia 14 September 2007. www.danadeclaration.org/pdf/SegoviaDeclaration.pdf.

Schlosberg, D. 2004. Reconceiving environmental justice: global movements and political theories. Environmental Politics 13 (3), 517-540.

Scott-Villiers, P. 2005. Covering letter for 'Rain, Prosperity and Peace. UNOCHA and IDS, 6 May, 2005.

Scott-Villiers, P., Stackpole-Moore, L., Stevens, J., Wheeler, J. 2005. Rain, Prosperity and Peace: Reporting from the Global Pastoralist Gathering, Turmi, Ethiopia 2005. Institute of Development Studies (IDS), University of Sussex, Brighton.

Sikor, T., Muller, D. 2009. The limits of state-led land reform: an introduction. World Development 37 (8), 1307-1316. 
Tschakert, P. 2009. Digging Deep for Justice: A Radical Re-imagination of the Artisanal Gold Mining Sector in Ghana. Antipode 41 (4), 706-740.

Turmi Global Pastoralist Gathering. 2005. Pastoralists and Pastoralism -Looking ahead to 2015. Report of Turmi Global Pastoralist Gathering $2^{\text {nd }}$ February 2005. http://www.danadeclaration.org/pdf/Global Pastoralist Gathering report.pdf

United Nations. 2008. United Nations Declaration on the Rights of Indigenous Peoples. http://www.un.org/esa/socdev/unpfii/documents/DRIPS en.pdf

Upton, C. 2012. Mining, resistance and pastoral livelihoods in contemporary Mongolia. In Dierkes, J. (Ed). Change in democratic Mongolia: social relations, health, mobile pastoralism and mining. Netherlands: Brill, pp. 223-248.

Visvanathan, S. 1998. A celebration of difference: science and democracy in India', Science 280, No. 5360, 42-43.

Walker, G. 2009a. Beyond distribution and proximity: exploring the multiple spatialities of environmental justice. Antipode 41 (4), 614-636.

Walker, G. 2009b.Globalizing environmental justice: the geography and politics of frame contextualization and evolution. Global Social Policy 9, 355-382.

Williams, G., Mawdsley, E. 2006. Postcolonial environmental justice: government and governance in India. Geoforum 37, 660-670.

World Alliance of Mobile Indigenous Peoples (WAMIP). 2004a. The World Alliance of Mobile Indigenous Peoples (WAMIP) Second General Meeting, Kuala Lumpur, Malaysia, February 9-13 and 16 2004. Unpublished report, WAMIP 2004a.

World Alliance of Mobile Indigenous Peoples (WAMIP). 2004b. Briefing Notes on Mobile Peoples and Conservation.

http://data.iucn.org/themes/ceesp/WAMIP/WAMIP\%20Briefing\%20Notes\%20Fall\%20 2004.pdf

World Initiative for Sustainable Pastoralism (WISP). 2013. Global Gathering of Pastoralists, Kiserian, Kenya, December 2013. Announcement available via WISP website at http://www.iucn.org/wisp/. (downloaded October $15^{\text {th }}, 2013$ ).

World Initiative for Sustainable Pastoralism (WISP). 2008. Policies that Work for Pastoral Environments: a Six Country Review of Positive Policy Impacts on Pastoral Environments. http://www.iucn.org/wisp/.

World Initiative for Sustainable Pastoralism (WISP). Undated. World Initiative for Sustainable Pastoralism. http://www.iucn.org/wisp/. 
World Parks Congress (WPC). 2003. Mobile Indigenous Peoples and Conservation. WPC Recommendation 27.

http://www.danadeclaration.org/pdf/recommendations27eng.pdf. 